\title{
Use of biochar in the composition of organic substrates for the production of papaya seedlings
}

\author{
Francisca Evelice Cardoso de Souza ${ }^{1 *} \mathbb{\oplus}$, William Natale ${ }^{1} \oplus$, Rosilene Oliveira Mesquita ${ }^{1} \oplus$,

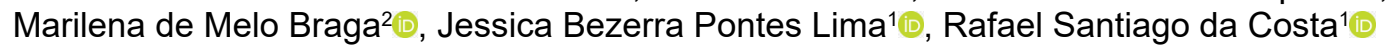

\footnotetext{
${ }^{1}$ Universidade Federal do Ceará, Fortaleza, CE, Brasil. E-mail: evelicesouza@gmail.com; natale@ufc.br; rosilenemesquita@ufc.br; jessicabplima@hotmail.com; rafaelsantiagodacosta@yahoo.com.br

${ }^{2}$ Instituto Federal do Maranhão, São Raimundo das Mangabeiras, MA, Brasil. E-mail: marilena.braga@ifma.edu.br
}

ABSTRACT: The technical aspects that involve the production of seedlings should be well studied to reduce the mistakes made in this phase. The present work aimed to evaluate biomass production, gas exchange and nutrient accumulation in papaya seedlings grown on substrates from organic residues, with or without the addition of green coconut shell biochar. The work was conducted in a greenhouse at the Federal University of Ceará, in Fortaleza, CE, Brazil. The experimental design adopted was completely randomized, consisting of eight treatments and four repetitions, with ten plants per repetition. The eight treatments comprised the substrates: composting sewage sludge, composting green coconut shell, composting carnauba bagana, commercial substrate Turfa Fértil囚, composting sludge + biochar, composting green coconut shell + biochar, composting bagana + biochar and commercial substrate + biochar. Biometric analyzes, gas exchange and accumulation of mineral elements were performed. Papaya seedlings showed higher quality when they were grown with sewage sludge, sludge + biochar and bagana + biochar, while the commercial substrate was not efficient, leading to a lower result for all variables. The addition of biochar was beneficial in all treatments in which it was used.

\section{Uso do biochar na composição de substratos orgânicos}

\section{para produção de mudas de mamoeiro}

RESUMO: Os aspectos técnicos que envolvem a produção de mudas devem ser bem estudados para reduzir os erros cometidos nessa fase. 0 presente trabalho objetivou avaliar a produção de biomassa, as trocas gasosas e 0 acúmulo de nutrientes em mudas de mamoeiro cultivadas em substratos provenientes de resíduos orgânicos, com ou sem a adição de biochar de casca de coco verde. O trabalho foi conduzido em casa de vegetação da Universidade Federal do Ceará, em Fortaleza, CE, Brasil. O delineamento experimental adotado foi o inteiramente casualizado, sendo formado por oito tratamentos e quatro repetições, com dez plantas por repetição. Os oito tratamentos compreenderam aos substratos: compostagem de lodo de esgoto, compostagem de casca de coco verde, compostagem de bagana de carnaúba, substrato

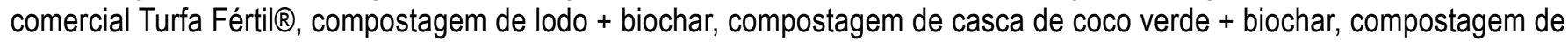
bagana + biochar e substrato comercial + biochar. Foram realizadas análises biométricas, de trocas gasosas e de acúmulo de elementos minerais. As mudas de mamoeiro exibiram maior qualidade quando foram cultivadas com lodo de esgoto, lodo + biochar e bagana + biochar, enquanto o substrato comercial não foi eficiente, tendo conduzido à resultado inferior para todas as variáveis. A adição de biochar foi benéfica em todos os tratamentos em que foi utilizado.

Palavras-chave: substrato alternativo; variáveis biométricas; Carica papaya L.; trocas gasosas; acúmulo de nutrientes

\footnotetext{
${ }^{*}$ Francisca Evelice Cardoso de Souza - E-mail: evelicesouza@gmail.com (Corresponding author)

Associate Editor: Clístenes Williams Araújo Nascimento
} 


\section{Introduction}

The papaya tree (Carica papaya L.) is a native fruit of the tropical regions, has a fast production, being frequent throughout the year. It is a widespread crop in Brazil, especially in the Northeast, contributing economically and socially due to the large volume of production (Sá et al., 2013), since in the year 2018 this region accounted for more than $50 \%$ of the national papaya production, with about one million tons having been produced in Brazil (IBGE, 2020).

Given the great importance of papaya and also because it is a perennial crop, special attention should be given to seedling production, since the quality of seedlings is paramount to ensure the uniformity of the orchard and good crop establishment (Matias et al., 2019). Therefore, the technical aspects that involve the production of seedlings, such as the use of substrates for example, must be well studied, since although there are numerous commercial substrates available, they are expensive and increase production costs.

In this sense, sustainable alternatives for the production of new substrates have been sought, such as the reuse of waste aiming to recycle nutrients and decrease production costs, besides mitigating negative environmental impacts (Araújo et al., 2017). The use of plant and animal wastes promote improvements in the chemical composition of substrates, since the decomposition of these materials provides the release of nutrients that were previously contained in the waste (Matias et al., 2019).

Among the organic residues that can compose substrates, green coconut shell, carnauba bagasse, and sewage sludge can be pointed out. Green coconut shell is the residue from the industrialization of coconut water and can be used as a raw material to produce agricultural inputs (Silva, 2014). Carnauba bagana is the byproduct of wax extraction from the carnauba leaf (Albano et al., 2017), and is employed as mulch and substrate. Sewage sludge is a semisolid waste coming from treatment plants, it is rich in nutrients and organic matter, which makes its potential for agricultural use high (Siqueira et al., 2018).

Another option for the adequate destination of organic residues is their use as biochar, which is a fine residue originating from the carbonization of biomass. Biochar has potential for use in substrates for seedling production, since it promotes changes in the physical-chemical characteristics of the support material (Basilio et al., 2020), increasing water retention and improving the efficiency of nutrient use (Lima et al., 2016), functioning as a substrate conditioner.

In this context, the present work aimed to evaluate the production of biomass, gas exchange and accumulation of nutrients in papaya seedlings grown in substrates from organic waste, with or without the addition of biochar produced from green coconut husk.

\section{Materials and Methods}

The experiment was conducted between March and April 2019, in a vegetation house belonging to the Department of
Plant Science, at the Pici Campus of the Federal University of Ceará (UFC), located in Fortaleza, CE, Brazil, which has as geographical coordinates: latitude $3^{\circ} 44^{\prime} \mathrm{S}$ and longitude $38^{\circ}$ 33' W.

For the production of the papaya seedlings, 50-cell polystyrene trays were used, with a capacity of $100 \mathrm{~mL}$ per cell. To do this, three seeds of papaya, variety Sunrise Solo, were sown in each cell at a depth of $1.5 \mathrm{~cm}$. At 20 days after sowing (DAS), when the plants had reached about $5 \mathrm{~cm}$ in height, thinning was performed, leaving the most vigorous plant in each cell. Irrigation was performed manually twice a day, until drainage of the applied water was observed. The weeds were removed manually as they appeared in the container, and no chemical fertilization was applied.

The experimental design adopted was entirely randomized, consisting of eight treatments and four repetitions, with ten plants in each repetition, totaling 320 papaya seedlings. The treatments consisted of eight substrates: sewage sludge composting, green coconut shell composting, carnauba bagana composting, commercial substrate Turfa Fértil ${ }^{\circledR}$, sludge + biochar composting, green coconut shell + biochar composting, bagana + biochar composting and commercial substrate + biochar. The biochar was produced from the green coconut shell, having been added in each treatment containing this component the proportion corresponding to $10 \%$ of the volume of the substrates.

The substrates were previously obtained through the process of aerobic composting for seven months. For this purpose, each residue was mixed with manure from laying hens, in the proportion of 3:1 (v/v); later, it was placed together with $50 \mathrm{~kg}$ of plaster in layers in windrows, which measured $1 \mathrm{~m}$ in height, $2 \mathrm{~m}$ in width and $2.5 \mathrm{~m}$ in length. The beds were turned once a week to speed up the composting process. After stabilizing, the composts were ground and sieved in a $4 \mathrm{~mm}$ mesh, to then be used in the production of seedlings (Oliveira et al., 2005).

The biochar was obtained by carbonizing the green coconut shell, after removing the coconut water for marketing and drying this residue in open air. For the production of biochar, the material was submitted to the pyrolysis process in a home oven, with a heating rate of $10 \stackrel{\circ}{ } \mathrm{min}^{-1}$, to a final carbonization temperature between 400 and $550 \stackrel{\circ}{C}$. Then, the biochar was sieved in a $2 \mathrm{~mm}$ mesh and added to the substrates for seedling production (Maia et al., 2013).

A commercial substrate was used in the experiment, the Turfa Fértil ${ }^{\circledR}$, which has peat and carbonized rice husk as raw materials. Regarding the residues used in the composting, the green coconut shell was donated by the company Agroindústria Paraipaba; the carnauba bagana and chicken manure were donated by Tijuca Alimentos; and the sewage sludge was supplied in dry form by the sewage treatment plant (ETE) of Fortaleza, belonging to the Companhia de Água e Esgoto do Estado do Ceará (Cagece).

The physical and chemical characterization of the substrates was performed in the soil laboratory of Embrapa Agroindústria Tropical, following the methodology defined 
by the Ministério da Agricultura, Pecuária e Abastecimento (Brasil, 2007). For the physical attributes, the overall density and water holding capacity were evaluated (Table 1). As for the chemical attributes, the water-soluble nutrients method was used, and the macronutrients, micronutrients, sodium, heavy metals, $\mathrm{pH}, \mathrm{EC}$, and CEC were analyzed (Table 2).

The papaya seedlings were evaluated at 27 DAS, and plant height was measured with the help of a ruler graduated in millimeters, from the neck to the last leaf insertion; the diameter of the stem obtained by measuring the neck of the plant with a digital pachymeter; and, the number of leaves, which was obtained by counting the fully developed leaves.

At 33 DAS, net photosynthetic rate (A), stomatal conductance $\left(g_{s}\right)$, and transpiration rate $(E)$ were measured. The evaluations were performed between 9:00 and 12:00 $h$, using constant photosynthetically active radiation (1200 $\mu$ mol photons $\mathrm{m}^{-2} \mathrm{~s}^{-1}$ ), constant $\mathrm{CO}_{2}$ concentration (400

Table 1. Overall density (Od) and water holding capacity (WHC) of organic waste-based substrates, Fortaleza, CE, Brazil, 2019.

\begin{tabular}{lcc}
\hline \multicolumn{1}{c}{ Substrate } & $\begin{array}{c}\text { Od } \\
\left(\mathbf{k g ~ m}^{-3}\right)\end{array}$ & $\begin{array}{c}\text { WHC } \\
(\%)\end{array}$ \\
\hline Commercial & 326 & 64 \\
Green coconut shell & 638 & 55 \\
Carnauba bagana & 627 & 53 \\
Sewage sludge & 645 & 52 \\
Comercial + biochar & 351 & 29 \\
Green coconut shell + biochar & 574 & 37 \\
Bagana + biochar & 582 & 31 \\
Sludge + biochar & 592 & 33 \\
\hline
\end{tabular}

ppm), ambient temperature and humidity, by means of an infrared gas analyzer (IRGA; portable model LI-6400XT, LI-COR Biosciences Inc., Lincon, Nebraska, USA). After measuring gas exchange, instantaneous water use efficiency $(A / E)$ and instantaneous carboxylation efficiency (A/Ci) were calculated.

At the end of the experiment, 34 DAS, the vegetative organs were collected and separated into aerial part and roots. The length of the main root was measured with a graduated ruler and the leaf area with a surface meter (LI - 3100, Área Meter, Li-Cor., Inc., Lincoln, 87 Nebraska, USA). The material was then washed in detergent water, in a $30 \%$ hydrochloric acid $(\mathrm{HCl})$ solution, and finally in deionized water; afterwards, the material was placed in identified paper bags and dried in an oven with forced air circulation at 65 oc until constant mass. After drying, the material was weighed on a precision digital scale to obtain the dry mass. The total dry mass was obtained by adding the dry masses of the aboveground part and the roots.

To estimate the quality of the seedlings, Dicksons quality index (DQI) was calculated. This index was obtained by means of a balanced formula using the variables total dry matter mass (TDMM), height $(H)$, stem diameter (SD), shoot dry matter mass (SDMM) and dry matter mass of root (DMMR) (Dickson et al., 1960), according to Equation 1.

$$
\mathrm{DQI}=\frac{\operatorname{TDMM}(\mathrm{g})}{\frac{\mathrm{H}(\mathrm{cm})}{\mathrm{SD}(\mathrm{mm})}+\frac{\operatorname{SDMM}(\mathrm{g})}{\operatorname{RDSM}(\mathrm{g})}}
$$

Table 2. Analysis of the chemical elements of the substrates: commercial (C), green coconut shell (CC), carnauba bagana (B), sewage sludge $(L)$, commercial + biochar $(C+B)$, green coconut shell + biochar $(C C+B)$, bagana + biochar $(B+B)$, and sludge + biochar (L + B), Fortaleza, CE, Brasil, 2019.

\begin{tabular}{|c|c|c|c|c|c|c|c|c|}
\hline \multirow{2}{*}{$\begin{array}{l}\text { Chemical } \\
\text { element }\end{array}$} & \multicolumn{8}{|c|}{ Substrate } \\
\hline & C & CC & B & L & $C+B$ & $\mathrm{CC}+\mathrm{B}$ & $B+B$ & $L+B$ \\
\hline $\mathrm{pH}$ & 5.5 & 6.7 & 6.4 & 6.4 & 5.8 & 6.8 & 6.6 & 6.4 \\
\hline $\mathrm{CE}\left(\mathrm{mS} \mathrm{cm}^{-1}\right)$ & 2.0 & 2.8 & 2.6 & 2.6 & 2.1 & 3.3 & 3.0 & 2.7 \\
\hline CTC $\left(\mathrm{mmol}_{\mathrm{c}} \mathrm{kg}^{-1}\right)$ & 870 & 201 & 225 & 210 & 707 & 452 & 134 & 194 \\
\hline $\mathrm{N}-\mathrm{NH}_{4}{ }^{+}\left(\mathrm{g} \mathrm{L}^{-1}\right)$ & 0.024 & 0.024 & 0.024 & 0.019 & 0.089 & 0.05 & 0.026 & 0.029 \\
\hline $\mathrm{N}-\mathrm{NO}_{3}^{-}\left(\mathrm{g} \mathrm{L}^{-1}\right)$ & 0.096 & 0.043 & 0.053 & 0.058 & 0.07 & 0.087 & 0.055 & 0.06 \\
\hline$P\left(\mathrm{~g} \mathrm{~L}^{-1}\right)$ & 0.001 & 0.027 & 0.052 & 0.024 & 0.034 & 0.021 & 0.002 & 0.020 \\
\hline $\mathrm{K}\left(\mathrm{g} \mathrm{L} \mathrm{L}^{-1}\right)$ & 0.06 & 0.14 & 0.16 & 0.16 & 0.71 & 0.77 & 1.17 & 0.74 \\
\hline $\mathrm{Ca}\left(\mathrm{g} \mathrm{L}^{-1}\right)$ & 1.74 & 2.57 & 2.47 & 1.85 & 2.35 & 2.47 & 1.38 & 1.36 \\
\hline $\mathrm{Mg}\left(\mathrm{g} \mathrm{L}^{-1}\right)$ & 0.33 & 0.63 & 0.52 & 0.24 & 0.38 & 0.53 & 0.27 & 0.18 \\
\hline$S\left(\mathrm{~g} \mathrm{~L}^{-1}\right)$ & 1.28 & 1.93 & 1.78 & 1.28 & 1.77 & 1.94 & 1.26 & 1.15 \\
\hline $\mathrm{Na}\left(\mathrm{g} \mathrm{L}^{-1}\right)$ & 0.14 & 0.08 & 0.08 & 0.07 & 0.12 & 0.14 & 0.26 & 0.13 \\
\hline $\mathrm{Zn}\left(\mathrm{mg} \mathrm{L}^{-1}\right)$ & 0 & 0 & 0 & 4.90 & 0 & 0 & 0 & 2.60 \\
\hline $\mathrm{Fe}\left(\mathrm{mg} \mathrm{L}^{-1}\right)$ & 1.4 & 0.15 & 0.20 & 0.50 & 0.20 & 0.15 & 0.70 & 0.45 \\
\hline $\mathrm{Mn}\left(\mathrm{mg} \mathrm{L}^{-1}\right)$ & 3.05 & 1.10 & 2.35 & 1.35 & 2.90 & 0.80 & 2.20 & 1.05 \\
\hline $\mathrm{Cu}\left(\mathrm{mg} \mathrm{L}^{-1}\right)$ & 0.05 & 0.10 & 0.10 & 0.95 & 0.05 & 0.10 & 0 & 0.95 \\
\hline $\mathrm{Al}\left(\mathrm{mg} \mathrm{L}^{-1}\right)$ & 1.00 & 0.70 & 1.10 & 1.05 & 1.15 & 0.65 & 0.65 & 1.10 \\
\hline $\mathrm{Ni}\left(\mathrm{mg} \mathrm{L}^{-1}\right)$ & 0 & 0.05 & 0 & 7.30 & 0 & 0.05 & 0 & 4.75 \\
\hline As $\left(\mathrm{mg} \mathrm{L}^{-1}\right)$ & 0 & 0 & 0 & 0 & 0 & 0 & 0 & 0 \\
\hline $\mathrm{Cd}\left(\mathrm{mg} \mathrm{L}^{-1}\right)$ & 0 & 0 & 0 & 0 & 0 & 0 & 0 & 0 \\
\hline $\mathrm{Cr}\left(\mathrm{mg} \mathrm{L}^{-1}\right)$ & 0.05 & 0.05 & 0.05 & 0.05 & 0.05 & 0 & 0 & 0.05 \\
\hline $\mathrm{Hg}\left(\mathrm{mg} \mathrm{L}^{-1}\right)$ & 0 & 0.05 & 0 & 0 & 0 & 0.05 & 0 & 0 \\
\hline $\mathrm{Pb}\left(\mathrm{mg} \mathrm{L}^{-1}\right)$ & 0 & 0 & 0 & 0 & 0 & 0 & 0 & 0 \\
\hline Se $\left(\mathrm{mg} \mathrm{L}^{-1}\right)$ & 0 & 0 & 0 & 0.15 & 0 & 0.05 & 0 & 0.15 \\
\hline
\end{tabular}

pH in water 1:5; EC - electrical conductivity; CEC - cation exchange capacity. 
After the dry biomass of the seedlings had been determined, the material was ground in a basic analytical mill, submitted to nitroperchloric digestion and taken to the Argon Plasma (ICP - OES) for determination of the macronutrient, micronutrient, sodium and heavy metal contents (Embrapa, 2009). The accumulation of mineral elements was calculated (A). To calculate the accumulation in the aerial part and in the roots, the expression was used: $A(\mathrm{mg})=$ SDMM or DMMR $x$ mineral element content. The total nutrient accumulation in the plant was obtained by summing the accumulation in the aboveground part and in the roots. In this study only the accumulation in the whole plant will be presented.

The analyzed data were submitted to variance analysis (ANOVA) and, when the $F$ test was significant at $5 \%$ or $1 \%$, the means were compared using Tukey test, using the computer program ASSISTAT 7.7 Beta.

\section{Results and Discussion}

All biometric variables were significantly affected by the treatments applied. The substrates sewage sludge and sludge + biochar promoted greater biometric performance, with superior results in all variables. In contrast to the other treatments, the commercial substrate provided higher average only in the main root length, originating seedlings with lower biometric development (Table 3).

The addition of biochar to the substrates was beneficial for seedling growth, promoting, in general, an increase in plant height $(H)$, stem diameter (SD), and number of leaves $(\mathrm{NL})$, compared to the substrates used alone. The higher concentration of nitrogen in the composition of the substrates with biochar (Table 2) stimulated the growth in plant height, given that this nutrient has a structural function, integrating carbon compounds in the plant (Taiz et al., 2017).

The increase in growth variables in substrates containing biochar results from the greater contribution of macronutrients in these treatments (Table 2), especially $\mathrm{N}$ and $\mathrm{K}$, which are required in large quantities by the papaya plant. The positive performance of the biochar also occurs due to the fact that this material contributes to the greater absorption of nutrients from the substrate. This result shows that the use of organic waste with good chemical composition makes it possible to reduce the use of chemical inputs, mitigating production costs, in addition to the fact that these materials promote direct and indirect effects on the quality of substrates and on the production of seedlings (Medeiros et al., 2015).

Plants grown on the commercial substrate showed lower results for height $(H)$, stem diameter $(S D)$, and number of leaves (NL). This negative effect of the commercial substrate Turfa Fértil ${ }^{\circledR}$ on growth variables is possibly due to the reduced concentration of nutrients in this substrate (Table 2), which impairs plant growth, as verified by Siqueira et al. (2018), in which the commercial substrate made with peat, coconut fiber, vermiculite, and pine bark provided the lowest growth of pink myrtle seedlings (Lafoensia glyptocarpa), in contrast, seedlings grown with sewage sludge exhibited superior growth due to the nutrient richness of the substrate.

Green coconut husk and carnauba bagasse, when used alone, promoted lower leaf area (LA) of the seedlings; On the other hand, when biochar was added to the mixture, there was an increase in LA, suggesting that these residues are more efficient when used in conjunction with other materials. The addition of biochar, in the substrates in which it was employed, was beneficial to the expansion of the leaf area of the seedlings. This positive effect of biochar on the expansion of the plant leaf area is a consequence of the greater availability of $\mathrm{N}$ in the composition of the substrates containing biochar (Table 2), since $\mathrm{N}$ regulates physiological and biochemical processes such as root development, leaf expansion and gene expression (Fernandes et al., 2018).

In opposition to the other biometric variables studied, the commercial substrate promoted superior results for main root length (CR). This fact occurred, possibly, due to the nutrient poverty of this substrate, because, under these conditions, the plant invests in the growth of the root system as a survival strategy for a greater absorption of essential elements. At low levels of nutrients, lower amounts of cytokinin occur in the

Table 3. Average values of biometric variables of papaya seedlings grown on commercial substrates (C), green coconut shell $(C C)$, carnauba bagana $(B)$, sewage sludge $(L)$, commercial + biochar $(C+B)$, green coconut shell + biochar $(C C+B)$, bagana + biochar $(B+B)$, and sludge + biochar $(L+B)$, Fortaleza, CE, Brazil, 2019.

\begin{tabular}{|c|c|c|c|c|c|c|c|c|c|}
\hline \multirow{2}{*}{ Treatments } & \multirow{2}{*}{$\begin{array}{c}\mathrm{H} \\
(\mathrm{cm})\end{array}$} & \multirow{2}{*}{$\begin{array}{c}\text { DC } \\
(\mathrm{mm})\end{array}$} & \multirow{2}{*}{ NF } & \multirow{2}{*}{$\begin{array}{c}\mathrm{AF} \\
\left(\mathrm{cm}^{2}\right)\end{array}$} & \multirow{2}{*}{$\begin{array}{c}\text { CR } \\
(\mathrm{cm})\end{array}$} & PMSA & PMSR & PMST & \multirow{2}{*}{ IQD } \\
\hline & & & & & & \multicolumn{3}{|c|}{ (g) } & \\
\hline $\mathrm{C}$ & $5.4 \mathrm{~b}$ & $1.6 \mathrm{~d}$ & $3.0 \mathrm{c}$ & $105.7 \mathrm{e}$ & $13.5 \mathrm{ab}$ & $0.4 \mathrm{e}$ & $0.4 \mathrm{~b}$ & $0.8 d$ & $0.2 \mathrm{c}$ \\
\hline $\mathrm{L}$ & $6.8 \mathrm{ab}$ & $2.2 \mathrm{a}$ & $4.0 \mathrm{a}$ & $315.4 \mathrm{abc}$ & $14.4 \mathrm{a}$ & $1.6 \mathrm{ab}$ & $0.6 \mathrm{ab}$ & $2.2 a b$ & $0.4 \mathrm{ab}$ \\
\hline $\mathrm{CC}$ & $6.8 \mathrm{ab}$ & $1.9 \mathrm{bcd}$ & $3.4 \mathrm{bc}$ & $227.6 \mathrm{~cd}$ & $15.2 \mathrm{a}$ & 0.9 cde & $0.5 \mathrm{ab}$ & $1.3 c$ & $0.3 \mathrm{bc}$ \\
\hline B & $7.0 \mathrm{a}$ & $2.1 \mathrm{ab}$ & $3.9 a b$ & $288.3 b c$ & $14.4 \mathrm{a}$ & $1.1 \mathrm{bcd}$ & $0.8 \mathrm{ab}$ & $1.9 \mathrm{~b}$ & $0.4 \mathrm{ab}$ \\
\hline$C+B$ & $6.3 a b$ & $1.7 \mathrm{~cd}$ & $3.4 \mathrm{bc}$ & 207.4 de & $15.1 \mathrm{a}$ & $0.8 \mathrm{de}$ & $0.4 \mathrm{~b}$ & $1.2 \mathrm{~cd}$ & $0.2 \mathrm{c}$ \\
\hline$L+B$ & $7.0 \mathrm{a}$ & $2.2 \mathrm{a}$ & $4.2 \mathrm{a}$ & 393.1 a & $15.4 \mathrm{a}$ & $1.6 \mathrm{ab}$ & $0.9 a$ & $2.5 a$ & $0.5 a$ \\
\hline$C C+B$ & $7.12 \mathrm{a}$ & $2.1 \mathrm{ab}$ & $3.9 a b$ & $350.3 \mathrm{ab}$ & $11.2 \mathrm{~b}$ & $1.4 \mathrm{abc}$ & $0.6 a b$ & $1.9 \mathrm{~b}$ & $0.3 \mathrm{bc}$ \\
\hline$B+B$ & $7.8 \mathrm{a}$ & $2.2 a$ & $4.0 \mathrm{a}$ & $377.7 \mathrm{ab}$ & $11.1 \mathrm{~b}$ & $1.7 \mathrm{a}$ & $0.7 a b$ & $2.4 a$ & $0.4 \mathrm{ab}$ \\
\hline Overall average & 6.75 & 1.99 & 3.73 & 283.2 & 13.77 & 1.18 & 0.61 & 1.79 & 0.33 \\
\hline CV $(\%)$ & 9.33 & 6.94 & 5.99 & 15.45 & 9.19 & 19.55 & 34.48 & 19.4 & 25.64 \\
\hline
\end{tabular}

$\mathrm{H}=$ height; $\mathrm{SD}=$ stem diameter; $\mathrm{NL}=$ number of leaves; $\mathrm{LA}=$ leaf area; $\mathrm{RL}=$ main root length; $\mathrm{SDMM}=$ shoot dry matter mass; $\mathrm{DMMR}=\mathrm{dry}$ matter mass of root; $\mathrm{TDMM}=$ total dry matter mass; $\mathrm{DQI}=$ Dickson quality index. Averages followed by the same letter do not differ statistically, in the columns, by Tukey test. 
plant, which is responsible for inhibiting root elongation, a condition that stimulates root development to the detriment of shoots (Epstein \& Bloom, 2006).

Although the seedlings grown on substrates green coconut shell, carnauba bagasse and commercial + biochar showed higher plant height $(\mathrm{H})$, the shoot dry matter mass (SDMM) and the total dry matter (TDM) of these plants were lower, suggesting that the plant height variable should not be analyzed in isolation to indicate seedling establishment in the field (Basilio et al., 2020), since the amount of dry matter accumulated can be low and growth without development in diameter causes stolonization.

Although the commercial substrate provided superior results for the main root growth (CR) of the seedlings, the lower nutrient input of this treatment did not allow the development of the root system in volume, which resulted in plants with lower root dry mass (RDM). This result highlights the importance of good nutritional composition of the substrates for the formation of seedlings with welldeveloped roots, as was recorded by Siqueira et al. (2018), in which myrindiba-rosa seedlings grown in substrate containing sewage sludge exhibited greater development of the root system due to the nutritional richness of the substrate.

Seedlings grown with green coconut husk + biochar and bagasse + biochar exhibited significant increment in total dry matter mass (TDMM) compared to TDMM of seedlings grown with green coconut husk and carnauba bagasse without the use of biochar. This positive effect of biochar confirms the importance of mixing different materials to compose substrates, since the materials, when used alone, will hardly meet the needs of the plant species (Siqueira et al., 2018); moreover, they may possess allelochemical substances and high $\mathrm{C} / \mathrm{N}$ ratio, so it is preferable to use two or more materials to form a good substrate (Lima et al., 2015).

Evaluating the IQD it was found that the seedlings from the sludge + biochar treatment exhibited the highest average, however, being statistically different from plants grown with sewage sludge, carnauba bagasse and bagana + biochar. The positive result of these organic residues on the seedling quality index shows the potential of the residues for use as plant substrate and to form quality papaya seedlings, since they produced seedlings with good biomass distribution, which favors the survival of the plants in the field due to the correct partition between vegetative and root growth (Lima et al., 2016).

The plants grown in the commercial substrate and commercial + biochar exhibited the lowest average IQD, however without statistical difference from the seedlings of the treatments green coconut shell and green coconut shell + biochar. These lower DQI values indicate seedlings of lower quality, since the higher the DQI value the higher the quality of the seedling (Siqueira et al., 2018), as well as suggesting future difficulties in seedling survival in the field due to unbalanced biometric development.

As for the physiological variables, only photosynthesis $(\mathrm{A})$, instantaneous carboxylation efficiency $(\mathrm{A} / \mathrm{Ci})$, and instantaneous water use efficiency (A/E) were significantly influenced by the treatments. The other variables studied were not affected by the treatments tested. The sludge + biochar substrate performed better, providing superior results in all physiological variables (Table 4).

All plants in the present study were subjected to partially controlled environmental conditions; in view of this, the differences in gas exchange observed are attributed to the characteristics of the substrates, with the nutrient composition of the treatments being the factor that most affected the physiological variables. Thus, the reduced photosynthetic rate (A) of the seedlings grown with carnauba bagasse and bagasse + biochar is possibly a consequence of the low concentration of $\mathrm{N}$ in the substrates (Table 2), which can decrease the production of chlorophyll and impair photosynthesis, since the net primary productivity of plants increases as a function of nutrient availability, especially N (Epstein \& Bloom, 2006).

In addition to the reduced net photosynthesis rate (A), seedlings grown on carnauba bagana, commercial + biochar and bagana + biochar substrates had low water use efficiency $(\mathrm{A} / \mathrm{E})$, that is, they lost the most water per unit of $\mathrm{CO}_{2}$ fixed, a situation that impairs plant metabolism since plants need to keep water inside. This lower water use efficiency should be considered when planning irrigation management in the nursery, since plants with low efficiency lose more water.

The good gas exchange performance of seedlings from the sludge + biochar substrate can be attributed to the higher growth of plants grown in this treatment, which increases plant physiological activity, and to the nutritional richness of this substrate. This situation corroborates the work of Santos et al. (2019), in which the highest mean gas exchange of orapró-nobis seedlings grown in substrate with chicken litter occurred as a function of the nutrient increment of this organic waste. The authors also observed that the higher efficiency of carboxylation $(\mathrm{A} / \mathrm{Ci})$ promoted by this substrate resulted in the potentiation of the photosynthetic rate, a situation also

Table 4. Average values of physiological variables of papaya seedlings grown on commercial substrates (C), green coconut shell (CC), carnauba bagana (B), sewage sludge (L), commercial + biochar $(C+B)$, coconut shell + biochar $(C C+B)$, bagana + biochar $(B+B)$ and sludge + biochar $(L+B)$, Fortaleza, $C E$, Brazil, 2019.

\begin{tabular}{cccccc}
\hline Treatment & $\mathrm{A}$ & $\mathrm{g}_{\mathrm{s}}$ & $\mathrm{E}$ & $\mathrm{A} / \mathrm{Ci}$ & $\mathrm{A} / \mathrm{E}$ \\
\hline $\mathrm{C}$ & $2.77 \mathrm{ab}$ & $0.14 \mathrm{~ns}$ & $1.4 \mathrm{~ns}$ & $0.008 \mathrm{ab}$ & $2.02 \mathrm{~b}$ \\
$\mathrm{~L}$ & $2.74 \mathrm{ab}$ & $0.14 \mathrm{~ns}$ & $1.4 \mathrm{~ns}$ & $0.008 \mathrm{ab}$ & $1.91 \mathrm{~b}$ \\
$\mathrm{CC}$ & $2.94 \mathrm{ab}$ & $0.14 \mathrm{~ns}$ & $1.4 \mathrm{~ns}$ & $0.008 \mathrm{ab}$ & $2.04 \mathrm{~b}$ \\
$\mathrm{~B}$ & $2.62 \mathrm{~b}$ & $0.14 \mathrm{~ns}$ & $1.5 \mathrm{~ns}$ & $0.007 \mathrm{~b}$ & $1.78 \mathrm{~b}$ \\
$\mathrm{C}+\mathrm{B}$ & $2.67 \mathrm{~b}$ & $0.14 \mathrm{~ns}$ & $1.4 \mathrm{~ns}$ & $0.007 \mathrm{~b}$ & $1.88 \mathrm{~b}$ \\
$\mathrm{~L}+\mathrm{B}$ & $4.08 \mathrm{a}$ & $0.14 \mathrm{~ns}$ & $1.4 \mathrm{~ns}$ & $0.012 \mathrm{a}$ & $2.90 \mathrm{a}$ \\
$\mathrm{CC}+\mathrm{B}$ & $2.84 \mathrm{ab}$ & $0.14 \mathrm{~ns}$ & $1.5 \mathrm{~ns}$ & $0.008 \mathrm{ab}$ & $1.92 \mathrm{~b}$ \\
$\mathrm{~B}+\mathrm{B}$ & $2.65 \mathrm{~b}$ & $0.14 \mathrm{~ns}$ & $1.4 \mathrm{~ns}$ & $0.007 \mathrm{~b}$ & $1.86 \mathrm{~b}$ \\
Overall average & 2.91 & 0.14 & 1.4 & 0.01 & 2.04 \\
CV (\%) & 19.69 & 1.74 & 5.19 & 21.44 & 18.07 \\
\hline A & &
\end{tabular}

$\mathrm{A}=$ photosynthesis; $\mathrm{gs}=$ stomatal conductance; $\mathrm{E}=$ transpiration; $\mathrm{A} / \mathrm{Ci}=$ instantaneous carboxylation efficiency; $A / E=$ instantaneous water use efficiency; $n s=$ not significant by Tukey's test; Averages followed by the same letter do not differ statistically, in the columns, by Tukey test. 
verified in the present study for the seedlings of the sludge + biochar treatment that exhibited high $\mathrm{A} / \mathrm{Ci}$ and $\mathrm{A}$.

Regarding the accumulation of macronutrients, the sodium element and micronutrients in the whole papaya plant, it was found that only iron did not show a significant response as a function of the treatments applied, while the other mineral elements were significantly influenced (Table 5).

Phosphorus was the macronutrient accumulated the least amount by the seedlings, while potassium was the macronutrient that accumulated the most. Although $P$ is absorbed in low amounts in the first year of papaya cultivation, its accumulation in the plant occurs in an increasing and uniform manner; $\mathrm{K}$ is one of the nutrients most required by this fruit tree, being required constantly and increasingly during the crop cycle, providing improvements in fruit quality (Oliveira et al., 2009). The macronutrients accumulated in the papaya seedlings in the following decreasing order: $\mathrm{K}, \mathrm{Ca}, \mathrm{Mg}, \mathrm{S}$, and $\mathrm{P}$.

The commercial substrate provided lower accumulation for all macronutrients evaluated. This fact resulted from the low growth and dry mass production of the plants grown in the commercial substrate Turfa Férti ${ }^{\circledR}$, considering that there is a direct relationship between the production of dry biomass and the accumulation of essential elements in the plants (Malavolta 2006), since the accumulation is the product of the nutrient content in the plant by the dry matter production.

The substrates with biochar promoted superior results in the accumulation of macronutrients, with the exception of the commercial treatment + biochar. Biochar, when incorporated into stabilized organic waste or when used as a composting agent, promotes synergistic interactions that can increase compost stability and improve nutrient availability (Toselli et al., 2020). Therefore, the use of this material is an environmentally friendly strategy for improving the fertility of substrates (Gonzaga et al., 2019).

For the accumulation of micronutrients it was found that, in general, this followed the same trend as the dry mass production of the plants, and the accumulation in the seedlings occurred in the following decreasing order: Fe $>\mathrm{Zn}$ $>\mathrm{Ni}>\mathrm{Cu}>\mathrm{Mn}$. Although Fe did not differ among treatments, this micronutrient accumulated the most in plants, a fact that corroborates what was observed by Oliveira et al. (2009), where Fe was the micronutrient with the highest rate of uptake by the aboveground part of the papaya plant.

Although the chemical analysis of the substrates quantified zinc only in the sewage sludge and in the sludge + biochar, the evaluation of the seedling tissues detected the presence of the element in the plants grown in all substrates. This was possibly due to the mineralization of $\mathrm{Zn}$ during the experiment and/or the ability of the plants to absorb a larger fraction of the elements than just the water-soluble concentration.

Unlike what occurred with the macronutrients, the use of biochar did not promote an increase in the accumulation of all the micronutrients in the seedlings, the results of which varied according to the type of residue. The addition of biochar to carnauba bagana promoted a reduction in the accumulation of micronutrients, while the use of biochar in the commercial substrate, in sewage sludge, and in green coconut husk provided greater accumulation. The causes of this effect of biochar on micronutrients need to be further investigated.

As for the accumulation of heavy metals, it was found that all the elements evaluated showed significant responses (Tables 6). It was not possible to quantify the accumulation

Table 6. Average values of the accumulation of heavy metals in the whole plant of papaya seedlings grown on commercial (C), green coconut shell (CC), carnauba bagana (B), sewage sludge (L), commercial + biochar $(C+B)$, coconut shell + biochar ( $C C$ $+B)$, bagana + biochar $(B+B)$ and sludge + biochar $(L+B)$ substrates, Fortaleza, CE, Brazil, 2019.

\begin{tabular}{|c|c|c|c|c|}
\hline \multirow{2}{*}{ Treatment } & $\mathrm{Al}$ & $\mathrm{Cr}$ & $\mathrm{Pb}$ & $\mathrm{Se}$ \\
\hline & \multicolumn{4}{|c|}{ (mg plant $\left.^{-1}\right)$} \\
\hline $\mathrm{C}$ & $1170.7 \mathrm{c}$ & $1.6 \mathrm{~b}$ & $1.0 \mathrm{c}$ & $0 \mathrm{c}$ \\
\hline $\mathrm{L}$ & $6155.8 \mathrm{a}$ & $15.5 \mathrm{a}$ & $6.5 a b$ & $10.0 \mathrm{a}$ \\
\hline $\mathrm{CC}$ & $2923.7 b c$ & $4.4 \mathrm{~b}$ & $1.8 \mathrm{C}$ & OC \\
\hline B & $3840.4 a b$ & $5.5 b$ & $3.5 \mathrm{bc}$ & $\mathrm{Oc}$ \\
\hline$C+B$ & $1785.0 \mathrm{bc}$ & $3.0 \mathrm{~b}$ & $1.8 \mathrm{C}$ & $\mathrm{OC}$ \\
\hline$L+B$ & $6305.4 \mathrm{a}$ & $24.3 \mathrm{a}$ & $8.1 \mathrm{a}$ & $10.0 \mathrm{a}$ \\
\hline $\mathrm{CC}+\mathrm{B}$ & $1246.5 b c$ & $3.9 \mathrm{~b}$ & $2.4 \mathrm{C}$ & $5.0 \mathrm{~b}$ \\
\hline$B+B$ & 1489.8 bc & $4.6 b$ & $1.8 \mathrm{C}$ & $1.0 \mathrm{c}$ \\
\hline Overall average & 3114.7 & 7.9 & 3.4 & 3.3 \\
\hline CV (\%) & 36.2 & 51.1 & 48.8 & 36.0 \\
\hline
\end{tabular}

Means followed by the same letter do not differ statistically, in the columns, by Tukey test.

Table 5. Average values of macronutrient, sodium element and micronutrient accumulation in the whole plant of papaya seedlings grown on commercial substrates $(C)$, green coconut shell $(C C)$, carnauba bagana (B), sewage sludge (L), commercial + biochar $(C+B)$, coconut shell + biochar $(C C+B)$, bagana + biochar $(B+B)$ and sludge + biochar $(L+B)$, Fortaleza, CE, Brazil, 2019.

\begin{tabular}{|c|c|c|c|c|c|c|c|c|c|c|c|}
\hline \multirow{2}{*}{ Treatment } & $\mathbf{P}$ & $\mathbf{K}$ & $\mathrm{Ca}$ & $\mathrm{Mg}$ & $S$ & $\mathrm{Na}$ & $\mathrm{Fe}$ & $\mathrm{Zn}$ & Mn & $\mathrm{Cu}$ & $\mathrm{Ni}$ \\
\hline & \multicolumn{11}{|c|}{ (mg plant ${ }^{-1}$ ) } \\
\hline$C$ & $1.4 \mathrm{~b}$ & $20 d$ & $11 d$ & $16.2 \mathrm{~b}$ & $5.7 \mathrm{~b}$ & $1.8 \mathrm{~d}$ & $661 \mathrm{~ns}$ & $104 \mathrm{~b}$ & $65 c$ & $13 c$ & $4 \mathrm{~b}$ \\
\hline $\mathrm{L}$ & $9.9 \mathrm{a}$ & $61 \mathrm{ab}$ & $45 a$ & $23.6 \mathrm{ab}$ & $15.3 \mathrm{a}$ & $9.0 \mathrm{a}$ & $1597 \mathrm{~ns}$ & $626 a$ & $80 \mathrm{abc}$ & $192 b$ & $390 a$ \\
\hline B & $10.7 \mathrm{a}$ & $45 \mathrm{bc}$ & $38 a b$ & 31.7 a & $15.8 \mathrm{a}$ & $5.3 \mathrm{bcd}$ & 793 ns & $179 \mathrm{~b}$ & $168 a$ & $49 c$ & $14 b$ \\
\hline$C+B$ & $2.0 \mathrm{~b}$ & $47 \mathrm{bc}$ & $18 \mathrm{~cd}$ & $17.0 \mathrm{~b}$ & $6.4 \mathrm{~b}$ & $4.5 \mathrm{~cd}$ & $1344 \mathrm{~ns}$ & $83 \mathrm{~b}$ & $82 a b c$ & $17 \mathrm{c}$ & $7 b$ \\
\hline$B+B$ & $9.8 \mathrm{a}$ & $73 a$ & $38 a b$ & $27.3 \mathrm{ab}$ & $15.7 \mathrm{a}$ & $8.7 a b$ & 3515 ns & $152 b$ & $155 a b$ & $42 c$ & $12 b$ \\
\hline Overall average & 7.3 & 50.9 & 30.6 & 23.5 & 13.0 & 6.0 & 1577.4 & 295.2 & 107.0 & 93.1 & 113.0 \\
\hline CV (\%) & 20.5 & 20.5 & 20.4 & 25.8 & 22.4 & 23.7 & 100 & 45.7 & 35.7 & 58.8 & 43.93 \\
\hline
\end{tabular}

ns = not significant by Tukey test; means followed by the same letter do not differ statistically, in the columns, by Tukey test. 
of arsenic, cadmium, and mercury, since the seedling tissue analysis did not detect the presence of these metals, which, however, does not indicate their absence in the plant tissue, which may be present in quantities below the detection limit of the argon plasma.

Although aluminum accumulated in significant amounts in the papaya seedlings of all treatments, there were no toxicity symptoms of this element, which manifest themselves first in the roots by promoting reduced growth of the main axis and inhibition of lateral root formation (Malavolta, 2006). No symptoms of toxicity by any of the heavy metals analyzed were observed during this study.

The treatments with sewage sludge promoted a higher accumulation of heavy metals in papaya seedlings; however, the concentration of these elements in the biosolids was within the range allowed by resolution 375/2006 of the National Council of the Environment (Brasil, 2006) for the use of sewage sludge as a substrate. These low values of heavy metals suggest that after transplanting the seedling to the field, sewage sludge will not promote soil contamination and can be safely used as a plant substrate, provided it is properly treated.

Similar to what was observed for micronutrients, the effect of biochar addition on heavy metal accumulation in plants varied as a function of the type of organic waste. This result stems from the fact that plant responses to biochar application vary by species, environmental conditions, soil type, biochar properties, and application rate (Toselli et al., 2020).

\section{Conclusions}

The substrates sewage sludge and sludge + biochar promoted the best performance of papaya seedlings. These treatments produced plants with superior biometric variables and adequate nutrient supply. The use of composted sewage sludge has not harmed plant production and can be safely used in agriculture.

The commercial substrate Turfa Fértil ${ }^{\circledR}$, when used alone or in association with biochar, was not efficient in the formation of seedlings, having produced plants with less biometric, physiological and nutritional development, therefore its use for the production of seedlings is not indicated papaya in polystyrene trays.

The addition of biochar, produced from the green coconut husk, in the proportion of $10 \%$ of the substrate volume, was beneficial to the treatments, having promoted changes in the physicochemical properties of the substrates and provided adequate seedling growth through the improvement of nutritional characteristics.

\section{Acknowledgments}

To the Conselho Nacional de Desenvolvimento Científico e Tecnológico (CNPq), for the financial support during the realization of this work.
To Embrapa Agroindústria Tropical, especially the Soil Laboratory and its employees, for providing the facilities to perform the analyses.

The companies Agroindústria Paraipaba, Tijuca Alimentos, and Companhia de Água e Esgoto do Estado do Ceará (Cagece), for donating the organic residues for the production of substrates.

\section{Compliance with Ethical Standards}

Author contributions: Conceptualization: $\mathrm{MMB}$; Data curation: FECS, JBPL, RSC; Formal analysis: WN, MMB; Funding acquisition: WN; Investigation: FECS, JBPL, RSC; Methodology: $M M B$; Project administration: WN, FECS; Resources: WN, ROM; Supervision: WN, ROM; Validation: WN, ROM, MMB; Visualization: FECS; Writing - original draft: FECS, WN; Writing - review \& editing: FECS, WN.

Conflict of interest: The authors declare that there are no conflicts of interest of a professional, personal or financial that could influence the article.

Funding: Conselho Nacional de Desenvolvimento Científico e Tecnológico (CNPQ).

\section{Literature Cited}

Albano, F.G.; Cavalcante, Í.H.L.; Machado, J.S.; Lacerda, C.F.; Silva, E.R.; Sousa, H.G. New substrate containing agroindustrial carnauba residue for production of papaya under foliar fertilization. Revista Brasileira de Engenharia Agrícola e Ambiental, v.21, n.2, p.128-133, 2017. https://doi.org/10.1590/1807-1929/agriambi.v21n2p128-133.

Araújo, E.F.; Aguiar, A.S.; Arauco, A.M.S.; Gonçalves, E.O.; Almeida, K.N.S. Crescimento e qualidade de mudas de paricá produzidas em substratos à base de resíduos orgânicos. Nativa, v.5, n.1, p.16-23, 2017. https://doi.org/10.31413/nativa.v5i1.3701.

Basílio, J.J.N.; Rodrigues, L.A.; Silva, M.S.A.; Colen, F.; Oliveira, L.S. Biochar de casca de pequi como componente de substrato para produção de mudas de Eucalyptus urophylla ST. Caderno de Ciências Agrárias, v.12, n.1, p.1-10, 2020. https://doi. org/10.35699/2447-6218.2020.24836.

Brasil. Ministério da Agricultura, Pecuária e Abastecimento - MAPA. Secretaria de Defesa Agropecuária. Instrução Normativa № 17, de 21 de maio de 2007. Aprova os Métodos Analíticos Oficiais para Análise de Substratos e Condicionadores de Solos, na forma do Anexo à presente Instrução Normativa. Diário Oficial da União, v.144, n.99, seção 1, p.8-9, 2007. https://www.gov. br/agricultura/pt-br/assuntos/insumos-agropecuarios/insumosagricolas/fertilizantes/legislacao/in-17-de-21-05-2007-aprovametodo-substrato.pdf. 22 Jun. 2020.

Brasil. Ministério do Meio Ambiente. Conselho Nacional do Meio Ambiente. Resolução Conama № 375, de 29 de agosto de 2006. Define critérios e procedimentos, para o uso agrícola de lodos de esgoto gerados em estações de tratamento de esgoto sanitário e seus produtos derivados, e dá outras providências. Diário Oficial da União, v.143, n.167, seção 1, p.141-146, 2006. http://www2. mma.gov.br/port/conama/res/res06/res37506.pdf. 22 Jun. 2020. 
Dickson, A.; Leaf, A.L.; Hosner, J.F. Quality appraisal of white spruce and white pine seedling stock in nurseries. The Forestry Chronicle, v.36, n.1, p.10-13, 1960. https://doi.org/10.5558/tfc36010-1.

Empresa Brasileira de Pesquisa Agropecuária - Embrapa. Manual de análises químicas de solos, plantas e fertilizantes. 2.ed. Brasília: Embrapa Solos, 2009. 627p.

Epstein, E.; Bloom, A. Nutrição mineral de plantas: princípios e perspectivas. 2.ed. Londrina: Editora Planta, 2006. 401p.

Fernandes, M.S.; Souza, S.R.; Santos, L.A. Nutrição mineral de plantas. Viçosa: Sociedade Brasileira de Ciência do Solo, 2018. 670p.

Gonzaga, M.I.S.; Almeida, A.Q.; Mackowiak, C.; Lima, I.S.; Santos, J.C.J.; Andrade, R.S. Nitrogen and phosphorus uptake efficiency in Indian mustard cultivated during three growth cycles in a copper contaminated soil treated with biochar. Ciência Rural, v.49, n.1, p.1-8, 2019. https://doi.org/10.1590/0103-8478cr20170592.

Instituto Brasileiro de Geografia e Estatística - IBGE. Produção Agrícola Municipal. 2020. https://sidra.ibge.gov.br/ tabela/5457\#resultado. 04 Jun. 2020.

Lima, R.L.S.; Severino, L.S.; Ferreira, G.B.; Sofiatti, V.; Sampaio, L.R.; Beltrão, N.E.M. Casca de mamona associada a quatro fontes de matéria orgânica para a produção de mudas de pinhãomanso. Revista Ceres, v.58, n.2, p.232-237, 2015. http://www.ceres. ufv.br/ojs/index.php/ceres/article/view/3739/1482. 04 Jun. 2020.

Lima, S.L.; Marimon Junior, B.H.; Melo-Santos, K.S.; Reis, S.M.; Petter, F.A.; Vilar, C.C.; Marimon, B.S. Biochar no manejo de nitrogênio e fósforo para a produção de mudas de angico. Pesquisa Agropecuária Brasileira, v.51, n.2, p.120-131, 2016. https://doi. org/10.1590/S0100-204X2016000200004.

Maia, C.M.B.F.; Lima, R.M.; Guiotoku, M. Efeito da temperatura final de carbonização nas propriedades físico-químicas do biocarvão da fibra do coco. Colombo: Embrapa Florestas, 2013. 4p. (Embrapa Florestas. Comunicado Técnico, 323). https://ainfo. cnptia.embrapa.br/digital/bitstream/item/94442/1/CT-323Claudia-Maia.pdf. 10 Feb. 2020.

Malavolta, E. Manual de nutrição mineral de plantas. 2.ed. São Paulo: Agronômica Ceres, 2006. 638p.

Matias, S.S.R.; Costa Junior, E.S.; Morais, D.B.; Silva, R.L.; Sousa, S.J.C. Substratos orgânicos na produção de mudas do mamoeiro havaí. Magistra, v.30, n.1, p.179-188, 2019. https:// magistraonline.ufrb.edu.br/index.php/magistra/article/ view/685/382. 25 Oct. 2020.
Medeiros, E.V.; Notaro, K.A.; Souza, B.M.; Silva, A.O.; Duda, G.P.; Silva, M.M. População microbiana, disponibilidade de nutrientes e crescimento de umbuzeiro em substratos contendo resíduos orgânicos. Revista Caatinga, v.28, n.3, p.47-53, 2015. https://doi. org/10.1590/1983-21252015v28n305rc.

Oliveira, A.M.G.; Aquino, A.M.; Castro Neto, M.T. Compostagem caseira de lixo orgânico doméstico. Cruz das Almas: Embrapa Mandioca e Fruticultura Tropical, 6p. 2005. (Embrapa Mandioca e Fruticultura Tropical. Circular Técnica, 76). https://www.infoteca. cnptia.embrapa.br/infoteca/bitstream/doc/1022380/1/ Compostagemcaseiradelixoorganicodomestico.pdf. 10 Jan. 2020.

Oliveira, A.M.G.; Souza, L.F.S.; Coelho, E.F. Mamoeiro. In: Crisóstomo, L.A.; Naumov, A. (Org.). Adubando para alta produtividade e qualidade: fruteiras tropicais do Brasil. Fortaleza: Embrapa Agroindústria Tropical, 2009. p.46-163.

Sá, F.V.S.; Brito, M.E.B.; Melo, A.S.; Antônio Neto, P.; Fernandes, P.D.; Ferreira, I.B. Produção de mudas de mamoeiro irrigadas com água salina. Revista Brasileira de Engenharia Agrícola e Ambiental, v.17, n.10, p.1047-1054, 2013. https://doi.org/10.1590/S141543662013001000004.

Santos, C.C.; Goelzer, A.; Silverio, J.M.; Scalon, S.P.Q.; Zárate, N.A.H.; Vieira, M.C. Capacidade vegetativa e trocas gasosas em mudas de Pereskia aculeata Plum em diferentes substratos. Scientia Plena, v.15, n.11, p.1-9, 2019. https://doi.org/10.14808/sci. plena.2019.110201.

Silva, A.C. Reaproveitamento da casca de coco verde. Revista Monografias Ambientais, v.13, n.5, p.4077-4086, 2014. https:// doi.org/10.5902/2236130815186.

Siqueira, D.P.; Carvalho, G.CM.W.; Barroso, D.G.; Marciano, C.R. Lodo de esgoto tratado na composição de substrato para produção de mudas de Lafoensia glyptocarpa. Floresta, v.48, n.2, p.277-284, 2018. https://doi.org/10.5380/rf.v48i2.55795.

Taiz, L.;Zeiger, E.; Moller, I.M.; Murphy, A. Fisiologia e Desenvolvimento Vegetal. 6.ed. Porto Alegre: Artmed, 2017. 858p.

Toselli, M.; Baldi, E.; Cavani, L.; Sorrenti, G. Nutrient management in fruit crops: an organic way. In: Srivastava, A.K.; Chengxiao, H.U. (Eds.). Fruit crops: Diagnosis and management of nutrient contraints. Amsterdam: Elsevier, 2020. p. 379-392. 